\title{
REACTION KINETICS OF CU ELECTRO-DEPOSITION ON THE SURFACE OF $\mathrm{TiO}_{2} /$ GRAPHITE
}

\author{
Fitria Rahmawati", Wanodya Anggit Mawasthi, Patiha \\ Research Group of Solid State Chemistry \& Catalysis, Universitas Sebelas Maret, \\ Jl. Ir. Sutami 36 A, Kentingan Surakarta 57126 telp. (0271) 663375 \\ email: fitria@mipa.uns.ac.id
}

\begin{abstract}
Research on the kinetics of electrode reaction during copper electro-deposition on the surface of $\mathrm{TiO}_{2} /$ graphite has been conducted. The aims of this research are to determine the ratio of anodic reaction rate to cathodic reaction rate $(\overline{\overline{r a} / r c})$, the ratio of anodic rate constant to cathodic rate constant $(\overline{\overline{k a} / \overline{k c}})$, the equilibrium constant when the reaction reach equilibrium condition and to study the polarization in the electro-deposition reaction. Copper was deposited electrochemically from $\mathrm{CuSO}_{4}$ solution at various concentration i.e. $0.1 \mathrm{M} ; 0.2 \mathrm{M} ; 0.3 \mathrm{M} ; 0.4$ $\mathrm{M} ; 0.5 \mathrm{M}$. In every 5 minutes during electro-deposition process, the $\mathrm{pH}$ changes in anode cell was recorded and the change of $\mathrm{Cu}^{2+}$ concentration was also analyzed by spectrophotometric method. The result shows that the reaction order of $\mathrm{Cu}^{2+}$ reduction is first order and the oxidation of $\mathrm{H}_{2} \mathrm{O}$ in anodic cell is zero order. The ratio of anodic rate constant to cathodic rate constant $(\overline{\overline{k a} / \overline{k c}})$, is $4.589 \times 10^{-3} \pm 0.071 \times 10^{-3}$. It indicates that the reaction rate in cathode is larger than the reaction rate in anode and it allowed polarization. The electrochemical cell reached equilibrium after 25 minutes with the equilibrium constant is $8.188 \times 10^{-10} \pm 1.628 \times 10^{-10}$.
\end{abstract}

Keywords: $\mathrm{Cu}$ Electro-deposition, $\mathrm{TiO}_{2} /$ Graphite, Kinetics of electrode reaction.

\section{INTRODUCTION}

Semiconductor materials play important role in human life such as for photocatalyst, sensor, electronic devices or solar cells. The photocatalyst powders have been applied for photocatalytic treatment of waste water, degradation of dye waste, disinfection treatment of water or fabrics etc. The immobilized form of photocatalyst such as in the form of thin layer on substrat has been studied intensively in order to reduce post treatment cost of separation between the product of photocatalytic degradation and its photocatalyst powder and also the immobilized form is easier to be recycled.

Immobilization of photocatalyst on a substrat has been investigated by some researchers such as Yang et $a l .{ }^{[1]}$ who succesfully grown mesoporous silica layer on graphite with the presence of surfactant cetyltrimethylammonium chloride (CTACl). The deposition method by using surfactant as linking agent is an innovation due to the method is unexpensive, no requirements of specific equipment and high temperature. Rahmawati et al. ${ }^{[2]}$ also deposited $\mathrm{TiO}_{2}$ film by chemical bath deposition with the assistance of surfactant molecules of cetyl trimethyl ammonium borate (CTAB).

$\mathrm{TiO}_{2}$ is a photo-catalyst for multivarious activities, in which the most promises property is its photocatalytic behaviour ${ }^{[3]}$ and relatively more chemically stable than other oxide materials ${ }^{[4]}$. $\mathrm{TiO}_{2}$ has been applied as photocatalyst to solve some environmental 
problems such as purification of water and air, destruction of microorganisms and inactivation of cancer cells ${ }^{[5]}$. $\mathrm{TiO}_{2}$ possesses several prominent advantages including high chemical resistance under highly acidic or basic medium, high mechanical strength that reduces the risk of breaking during reaction ${ }^{[6]}$.

The performance as photocatalyst can be reduced due to the recombination phenomena between the excited electrons and the positively leaving holes? ${ }^{7}$. Therefore some reseachers did some efforts to reduce the recombination phenomena, such as by combining with other semiconductor to form coupling semiconductor, depositing metal on the semiconductor surface etc. Metal surface deposition has proven can increases the photocatalytic activity of $\mathrm{TiO}_{2}$ by reducing the recombination phenomena. The deposited metal can serves as electrons trapper and allows the holes to migrate to the surface of semiconductor and act as oxidator for the targeted molecules. Meanwhile, the electrons that carry the negative charge can act as reductor. In order to deposite metal on the semiconductor surface, there are many methods that can be used such as chemical deposition, sputtering, coating or electrodeposition. In this research, the electrodeposition method was chosen due to the $\mathrm{TiO}_{2}$ layer was deposited on a conductive substrate, i.e graphite. The conductive property of graphite allows an electroassisted deposition is possible to be applied. The preparation of $\mathrm{TiO}_{2}$ layer on graphite was conducted by chemical bath deposition as it was conducted in our previous researches ${ }^{[2,8]}$. Graphite was also used as catalyst supports ${ }^{[9]}$. Meanwhile, Zhu et al. ${ }^{[10]}$ used carbon-titania composite as catalyst support.

The electro-deposition of $\mathrm{Cu}$ from $\mathrm{CuSO}_{4}$ solution has been conducted previously by our group and showed that the $\mathrm{Cu}$ deposition increases the photocatalytic activity of $\mathrm{TiO}_{2} / \mathrm{Graphite}^{[2]}$. It was found that electrodeposition of $\mathrm{Cu}$ on $\mathrm{TiO}_{2} /$ Graphite did not follow Faraday's Law as it described in equation (1) that the weight of deposited metal is in linear relationship with the applied current and time of electrodeposition. This research investigated whether the deviation from Faraday's law is caused by the $\mathrm{Cu}^{2+}$ reduction into $\mathrm{Cu}$ reaches equilibrium after a definited time or it is caused by loss of the deposited $\mathrm{Cu}$. Therefore, in this research the concentration of $\mathrm{Cu}^{2+}$ during electro-deposition process was measured continuously at every definited time by using UV-Vis spectroscopy. Meanwhile, the proceed of anodic reaction was recorded through $\mathrm{pH}$ measurements. The $\mathrm{pH}$ value is refer to the concentration of $\mathrm{H}^{+}$ which was produced by oxidation reaction of $\mathrm{H}_{2} \mathrm{O}$.

$$
w=\frac{M . i . t}{n .96500}
$$

Where gw is the weight of the deposited metal (g), $M$ is the relative molecular $\operatorname{mass}\left(\mathrm{g} \cdot \mathrm{mol}^{-1}\right), n$ is the number of electrons involved in the reaction, $i$ is the applied current (Ampere), $t$ is time of electrodeposition (second) and 96,500 is the Faradaic constant.

\section{MATERIALS AND METHODS}

Titanium (IV) chloride (Merck) was used as titanium dioxide precursor, the graphite rods from $\mathrm{ABC}$ battery industry were sliced into tablets and used as substrate for $\mathrm{TiO}_{2}$ layer. The $\mathrm{TiO}_{2}$ layer was coated on graphite substrate by chemical bath deposition method (CBD) at acidic condition of $\mathrm{HCl} 37 \%$ and the surfactant molecules of cetyl trimethyl ammonium bromide (CTAB). $\mathrm{Cu}$ was deposited from $\mathrm{CuSO}_{4}$ solution which was prepared by dissolving $\mathrm{CuSO}_{4} \cdot 5 \mathrm{H}_{2} \mathrm{O}$ (Merck) in deionized water.

The graphite tablets were heated at $105{ }^{\circ} \mathrm{C}$ for 1 hour. After being cooled at room temperature, the discs then to be weighing analytically. Those gravimetrical procedure were conducted until the weight of graphite disc is constant (the weight different is less than $0.02 \mathrm{~g}$ ). After the gravimetrical weighing of the graphite discs were noted, $\mathrm{TiO}_{2}$ layer then to be coated on graphite disc by CBD method. A $100 \mathrm{~mL}$ solution that contain of $8.3 \mathrm{~mL}$ of $1 \mathrm{M} \mathrm{HCl}$ solution and $1.1 \mathrm{~mL}$ of $1 \mathrm{M} \mathrm{TiCl}_{4}$ solution was prepared as the precursor for $\mathrm{TiO}_{2}$ layer. The detail procedure on $\mathrm{TiO}_{2}$ layer preparation is 
described our previous paper ${ }^{8}$. The produced $\mathrm{TiO}_{2} /$ graphite was then to be characterized by $\mathrm{X}$-ray diffraction (Shimadzu 6000) to analyzed its phases and its crystallinity.

The electro-deposition was conducted by using Analytic Analyzer Electrolysis Yanaco AES-2D with accuracy of $1 \times 10^{-2}$ volt. A digital multimeter, Fluke 73 Series was used to record electrical current pass through the electrochemical cell, the potential of cathode and the potential of anode at every 5 minutes. $\mathrm{Cu}$ was deposited from a series of $\mathrm{CuSO}_{4}$ solution i.e. $0.1 \mathrm{M} ; 0.2 \mathrm{M} ; 0.3 \mathrm{M} ; 0.4 \mathrm{M}$ and $0.5 \mathrm{M}$. The $\mathrm{TiO}_{2}$ /graphite was used as cathode and a graphite rod was used as anode. A constant current of $0.02 \mathrm{~A}$ was applied to the electrochemical cell. A glass electrode of $\mathrm{pH}$ meter was dipped into the electrochemical cell to record the $\mathrm{pH}$ of water as the result of oxidation of $\mathrm{H}_{2} \mathrm{O}$. Meanwhile, in every 5 minutes, $\mathrm{Cu}^{2+}$ concentration was measured by using UV-Vis spectrophotometer, double beam Shimadzu 1601 PC. The light wavelength of maximum absorbance of $\mathrm{CuSO}_{4}$ solution was determined and it was $810 \mathrm{~nm}$. Then, a standard absorbance curve of $\mathrm{CuSO}_{4}$ solution was plotted. The curve was used to determine the $\mathrm{Cu}^{2+}$ concentration from its absorbance values. The design of electro-deposition cell is described in Figure 1. The prepared $\mathrm{Cu}-$ $\mathrm{TiO}_{2} /$ graphite then to be weighted gravimetrically. The kinetics study on the electrode reactions were carried out by determining the comparison of anodic reaction rate to cathodic reaction rate $\left(r_{a} / r_{c}\right)$ and the ratio of anodic reaction rate constant to cathodic reaction rate constant $\left(\mathrm{k}_{\mathrm{a}} / \mathrm{k}_{\mathrm{c}}\right)$. Each experiment was conducted three times (triple).

\section{RESULTS AND DISCUSSION}

In order to analyse the $\mathrm{TiO}_{2}$ layer that was deposited by CBD method on graphite substrat and the $\mathrm{Cu}$ deposite on $\mathrm{TiO}_{2} /$ Graphite, the prepared materials were analyzed by X-ray diffraction at $2 \theta$ of $10^{\circ}$ $90^{\circ}$. The diffraction patterns are depicted in Figure 2.

The diffraction pattern of the prepared materials, Figure 2, were compared to the $d$ spacing values of anatase $\mathrm{TiO}_{2}$ and rutile $\mathrm{TiO}_{2}$ standard diffraction according to JCPDS \#. It was found that the prepared $\mathrm{TiO}_{2}$ layer is present in anatase and rutile. Highest anatase peak is at $2 \theta 54.1441^{\circ}$ and the highest rutile peak is at $2 \theta 43.8402^{\circ}$. The $\mathrm{Cu}$ peaks are identified at $2 \theta 43.37^{\circ}, 2 \theta 50.60^{\circ}$ and $2 \theta 74.22^{\circ}$. The peaks were identified based on $\mathrm{Cu}$ standard diffraction ICSD\# 43493. Scherrer equation was used to estimate the crystallite size of particles, and showed that the crsytallite size of rutile is $9.74 \mathrm{~nm}$, the crystallite size of anatase is 9.75 $\mathrm{nm}$ and the deposited $\mathrm{Cu}$ is $26.32 \mathrm{~nm}$.

The redox (reduction-oxidation) reaction during electro-deposition are as listed in equation (2) and (3).

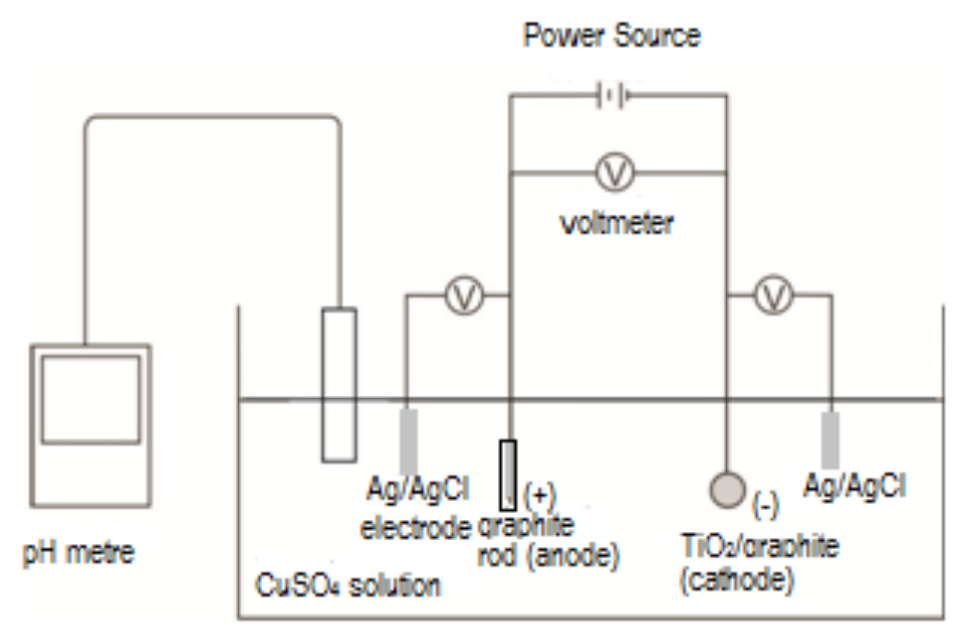

Figure 1. The scheme of electro-deposition cell. 


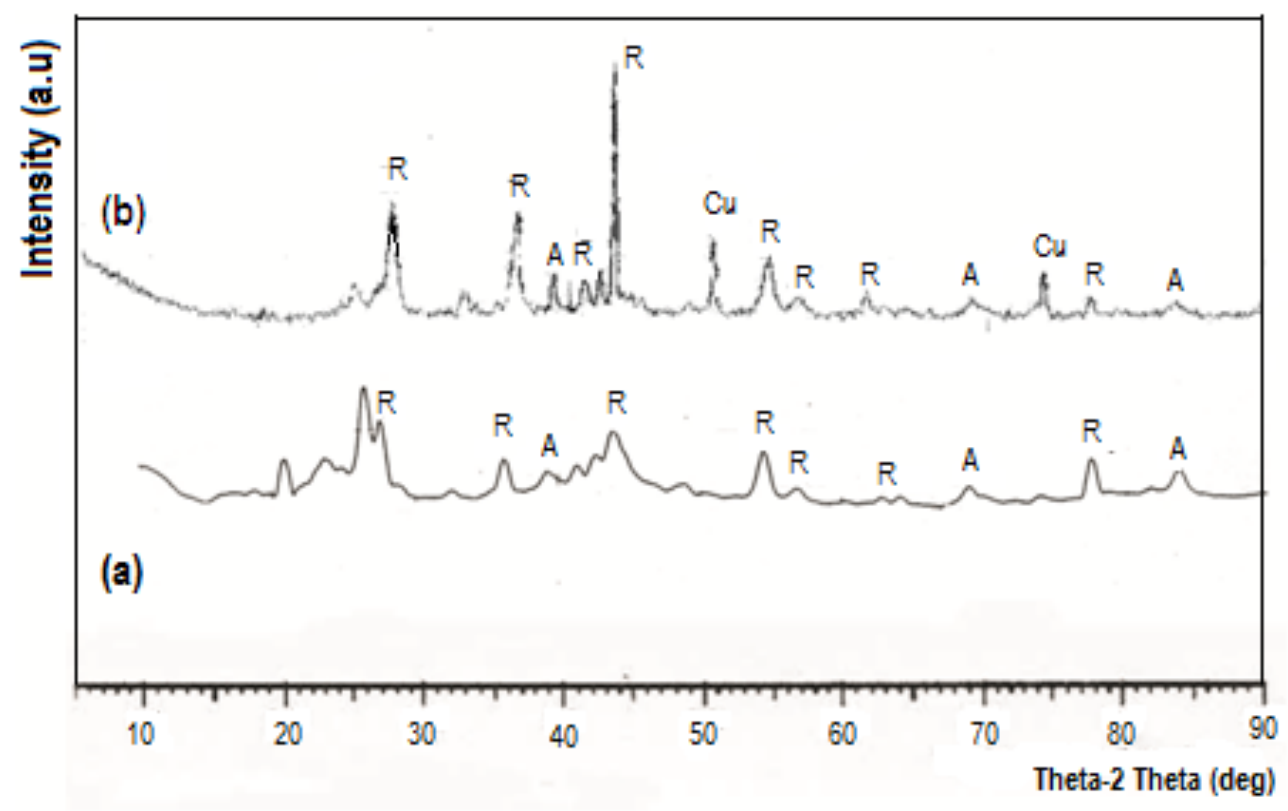

Figure 2. The diffraction patterns of a) $\mathrm{TiO}_{2}$ /graphite and (b) $\mathrm{Cu}-\mathrm{TiO}_{2}$-graphite. $\mathrm{R}$ is rutile, $\mathrm{A}$ is anatase and $\mathrm{Cu}$ is copper peak.

Cathodic reaction:

$\mathrm{Cu}^{2+}{ }_{(\mathrm{aq})}+2 \mathrm{e} \underset{\mathrm{E}^{\circ}=+0.340 \mathrm{Volt}^{(\mathrm{s})}}{\mathrm{Cu}^{\circ}}$

Anodic reaction:

$$
\mathrm{H}_{2} \mathrm{O}_{(\mathrm{l})} \longrightarrow \mathrm{E}^{\cdot}=-1.230 \operatorname{Volt}(3)
$$

Total reaction:

$$
\mathrm{Cu}^{2+}+\mathrm{H}_{2} \mathrm{O} \longrightarrow \mathrm{Cu}+2 \mathrm{H}^{+}+{ }_{1} / 2 \mathrm{O}_{2}
$$

After 25 minutes of electro-deposition, the absorbance of $\mathrm{Cu}^{2+}$ solution was constant, as it is described in Figure 3. It indicates that the reaction of $\mathrm{Cu}^{2+}$ into $\mathrm{Cu}$ reached equilibrium after 25 minutes. Therefore, the reaction kinetics study was conducted on the data before 25 minutes of electro-deposition time.

The determination of reaction order was conducted by plotting ln A versus $t$ (minutes) for first order and 1/A versus $t$ (minutes) for second order. The suitable reaction order was chosen based on the value of linearity constant, R, which are listed in Table 1. The graphics of and its linear equations are depicted in Figure 4.

a

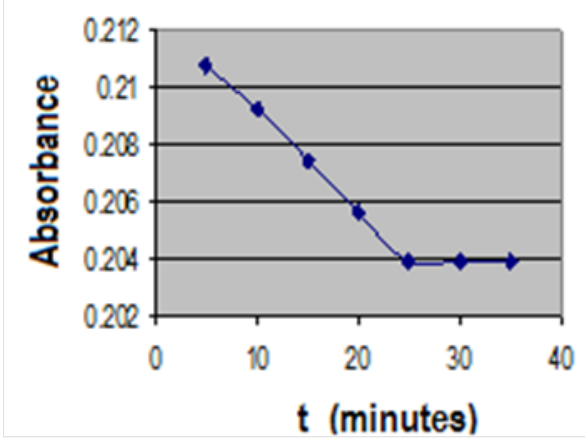

b

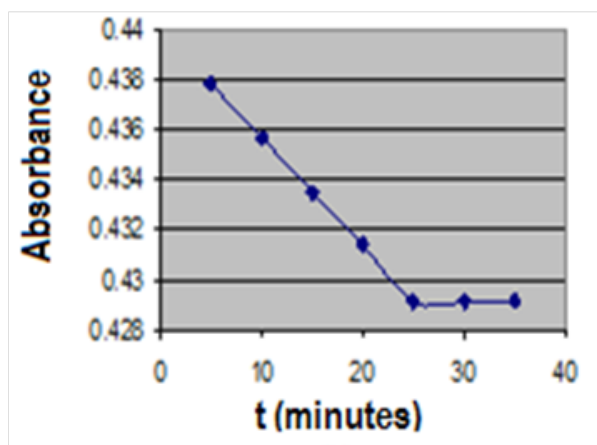

Figure 3. Plot of $\mathrm{A}$ versus time during $\mathrm{Cu}$ electro-deposition from (a) $0.1 \mathrm{M}$ of $\mathrm{CuSO}_{4}$ solution and (b) $0.2 \mathrm{M}$ of $\mathrm{CuSO}_{4}$ solution. 
Table 1. The linearity constants of first order and second order plot

\begin{tabular}{ccc}
\hline $\begin{array}{c}{\left[\mathrm{Cu}^{2+}\right]} \\
(\text { Molar})\end{array}$ & $\begin{array}{c}\mathrm{R}^{2} \\
\left(1^{\text {st }}\right. \\
\text { order })\end{array}$ & $\begin{array}{c}\mathrm{R}^{2} \\
\left(2^{\text {nd }}\right. \\
\text { order })\end{array}$ \\
\hline 0.1 & 0.9996 & 0.9993 \\
0.2 & 0.9998 & 0.9996 \\
0.3 & 0.9998 & 0.9996 \\
0.4 & 0.9999 & 0.9995 \\
0.5 & 1.0000 & 0.9999 \\
\hline
\end{tabular}

The electrochemical kinetics study of $\mathrm{Cu}$ deposition was described according to Buttler-Volmer equation (equation (4)) ${ }^{[10]}$.

$j=j_{o}\left\{\exp \left[(1-\alpha) \frac{n F}{R T} \eta\right]-\exp \left[-\alpha \frac{n F}{R T} \eta\right]\right\}$

Where $j$ represents the current density, $\eta$ is the overpotential, $j_{o}$ is the exchange current density, $n$ is the number of exchanged electrons, $T$ is the temperature and $\alpha$ is the cathodic transfer coefficient or named as symmetric factor. If the cathodic transfer coefficient is 0.5 , therefore the anodic transfer coefficient will also 0.5 . It means that the symtrical factor of the electrochemical reaction is 0.5 .

By considering that symmetric factor is 0.5 for anode reaction and 0.5 for cathode reaction, therefore the electrode reaction rate were calculated by equation (5) and (6). The equations are derived from the reaction rate as described in Prentice ${ }^{[11]}$.

$$
\begin{aligned}
& r a=k_{a}^{\prime} C_{R} \exp \left\{\frac{0,5 n F \Phi}{R T}\right\} \\
& r c=k_{c}^{\prime} C_{o} \exp \left\{\frac{-0,5 n F \Phi}{R T}\right\}
\end{aligned}
$$

Where $r a$ is the anodic reaction rate, $r c$ is the cathodic reaction rate, $n$ is the number of electrons contribute into the reaction, $F$ is Faradaic number, $R$ is the gas constant, $T$ is temperature, $C_{R}$ is the concentration of reducted species, $C_{o}$ is the concentration of oxidized species and $\Phi$ is the potential of electrode during the reaction. Meanwhile, the anodic rate constant, $k a$, and the cathodic rate constant, $k c$, are expressed by equation (7) and (8).

$k a=k_{a}^{\prime} \exp \left\{\frac{(1-\beta) n F \Phi}{R T}\right\}$

$k c=k_{c}^{\prime} \exp \left\{\frac{-\beta n F \Phi}{R T}\right\}$

Where $\beta$ is symmetrical factor with values range from $0-1$. It is a fraction of potential different in the electrical double layer of cathodic reaction. The value is ussually 0.5 , with the assumption that anodic and cathodic are symmetrical. If the value of $\beta$ is zero, it means that there are no energy promoted in cathodic reaction [11].

By substituting equation (7) into (5) and (8) into (6), therefore the ratio of anodic reation rate and cathodic reaction rate can be expressed as equation (9).

$\frac{r_{a}}{r_{c}}=\frac{k_{a}}{k_{c}} \frac{C_{R}}{C_{o}}$

$r_{a} / r_{c}$ is the ratio of anodic reaction rate and cathodic reaction rate, $C_{R}$ is concentration of the reduced species, which is $\mathrm{Cu}^{2+}$ and $C_{O}$ is concentration of the oxidized species, which is $\mathrm{H}_{2} \mathrm{O}$. The ratio of anodic reaction rate to cathodic reaction rate, $\mathrm{ra} / \mathrm{rc}$ are listed in Table 2.

Meanwhile, reaction order of $\mathrm{H}_{2} \mathrm{O}$ in anodic reaction was determined from linear plotting of $\mathrm{H}_{2} \mathrm{O}$ concentration against/versus time, before the reaction reach equilibrium. The $\mathrm{H}_{2} \mathrm{O}$ was determined based on $\mathrm{pH}$ data during reaction which represented the $\mathrm{H}^{+}$ concentration, $\left[\mathrm{H}^{+}\right]$. Based on equation (3) it is known that the concentration of $\mathrm{H}_{2} \mathrm{O}$ that oxidized into $\mathrm{O}_{2}$ and $\mathrm{H}^{+}$is similar to 0.5 times $\left[\mathrm{H}^{+}\right]$. The calculation results are listed in Table 3. Table 3 shows that the anodic reaction is proceed with zero order with rate law described in equation (10).

$\mathrm{r}_{\mathrm{a}}=\mathrm{k}_{\mathrm{a}}\left[\mathrm{H}_{2} \mathrm{O}\right]^{0}=\mathrm{k}_{\mathrm{a}}$ 
a

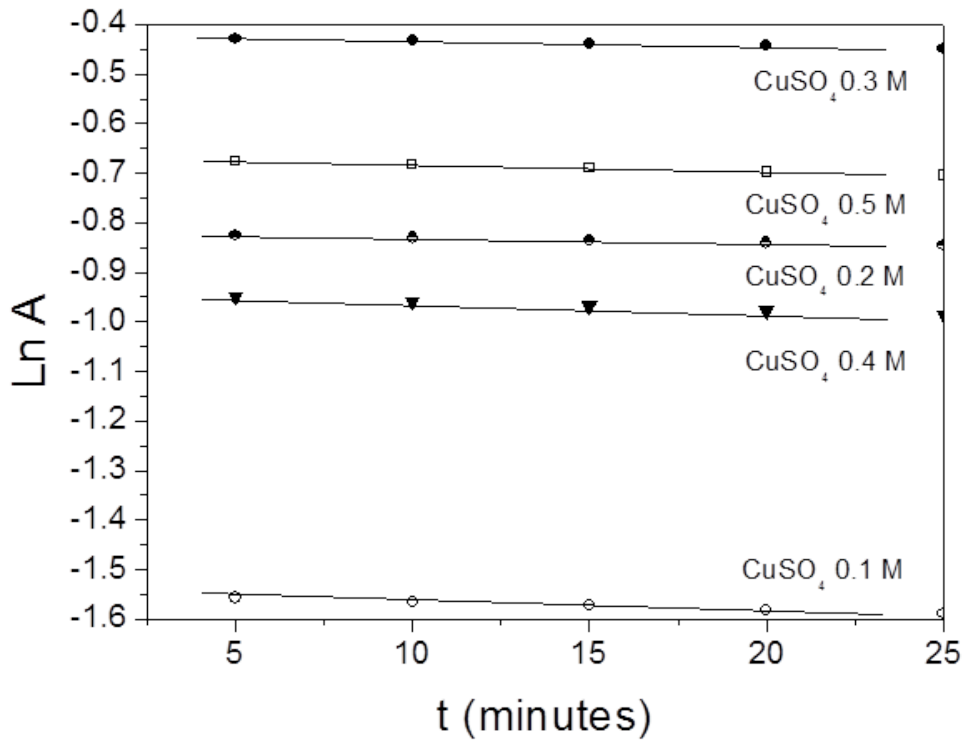

b

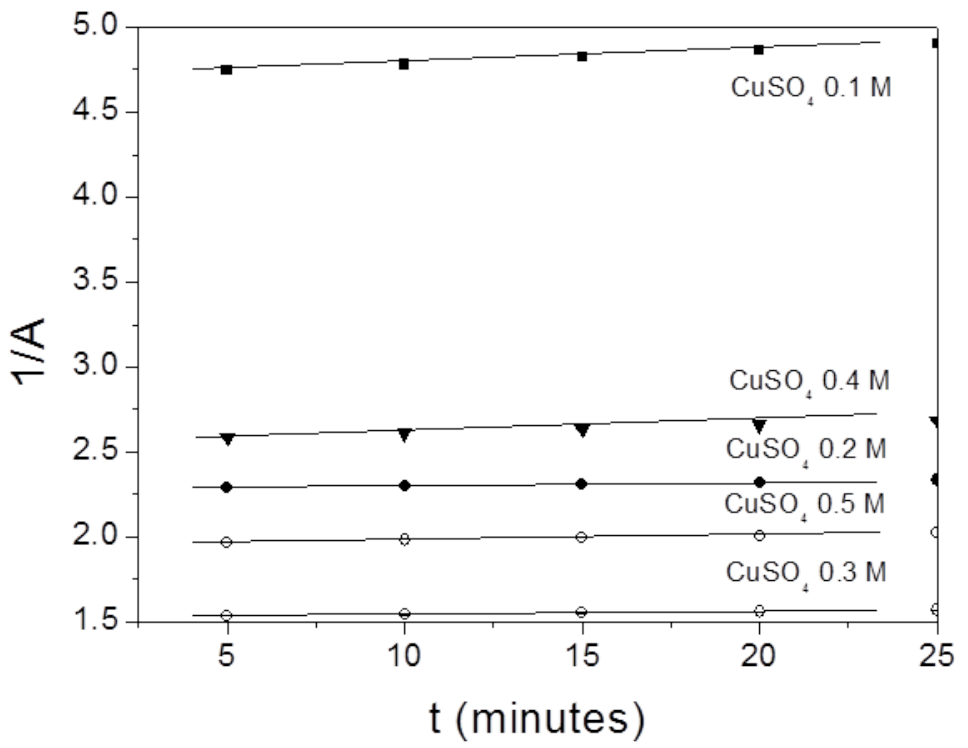

Figure 4. Plot to determine the reaction order (a) first order plot and (b) second order plot.

Tabel 2. The ratio of anodic reaction rate, $r_{a}$ to cathodic reaction rate, $r_{c}$.

\begin{tabular}{lllll}
\hline $\begin{array}{l}{\left[\mathrm{Cu}^{2+}\right]} \\
\begin{array}{l}\bar{c} \text { concentration } \\
\text { (Molar) }\end{array}\end{array}$ & $\begin{array}{l}\overline{r a} / r c \\
\text { experiment 1 }\end{array}$ & $\begin{array}{l}\overline{r a} / r c \\
\text { experiment 2 }\end{array}$ & $\begin{array}{l}\overline{r a} / r c \\
\text { experiment 3 }\end{array}$ & $\begin{array}{l}\text { The average } \\
\overline{r a} / r c\end{array}$ \\
\hline 0.1 & $3.755 \times 10^{-2}$ & $4.044 \times 10^{-2}$ & $3.582 \times 10^{-2}$ & $3.794 \times 10^{-2}$ \\
0.2 & $3.147 \times 10^{-2}$ & $2.487 \times 10^{-2}$ & $3.138 \times 10^{-2}$ & $2.924 \times 10^{-2}$ \\
0.3 & $2.061 \times 10^{-2}$ & $2.302 \times 10^{-2}$ & $2.160 \times 10^{-2}$ & $2.174 \times 10^{-2}$ \\
0.4 & $8.646 \times 10^{-3}$ & $9.551 \times 10^{-3}$ & $8.691 \times 10^{-3}$ & $8.963 \times 10^{-3}$ \\
0.5 & $8.856 \times 10^{-3}$ & $9.716 \times 10^{-3}$ & $8.850 \times 10^{-3}$ & $9.141 \times 10^{-3}$ \\
\hline
\end{tabular}


Meanwhile, reaction order of $\mathrm{H}_{2} \mathrm{O}$ in anodic reaction was determined from linear plotting of $\mathrm{H}_{2} \mathrm{O}$ concentration against/versus time, before the reaction reach equilibrium. The $\mathrm{H}_{2} \mathrm{O}$ was determined based on $\mathrm{pH}$ data during reaction which represented the $\mathrm{H}^{+}$ concentration, $\left[\mathrm{H}^{+}\right]$. Based on equation (3) it is known that the concentration of $\mathrm{H}_{2} \mathrm{O}$ that oxidized into $\mathrm{O}_{2}$ and $\mathrm{H}^{+}$is similar to 0.5 times $\left[\mathrm{H}^{+}\right]$. The calculation results are listed in Table 3. Table 3 shows that the anodic reaction is proceed with zero order with rate law described in equation (10).

$\mathrm{r}_{\mathrm{a}}=\mathrm{k}_{\mathrm{a}}\left[\mathrm{H}_{2} \mathrm{O}\right]^{0}=\mathrm{k}_{\mathrm{a}}$

The anodic reaction rate is similar to the value of its reaction rate constant, $\mathrm{k}_{\mathrm{a}}$. If the reaction rate is determined from the production of $\mathrm{H}^{+}$which was recorded during electro-deposition process, therefore, the linear regression plot of $\left[\mathrm{H}^{+}\right]$versus time produces slope which represent the rate constant, $\mathrm{k}_{\mathrm{a}}$. Table 4 shows the ratio of anodic rate constant to cathodic rate constant, $\mathrm{k}_{\mathrm{a}} / \mathrm{k}_{\mathrm{c}}$. Cathodic reaction rate constant, $\mathrm{k}_{\mathrm{c}}$, was determined from slope value of plot between absorbance of $\mathrm{Cu}^{2+}$ solution over time (minutes).

The ratio of anodic rate constant to cathodic rate constant as listed in Table 4, show that the cathodic reaction was proceed faster than anodic reaction. In general the electro-deposition of metal usually has high current density exchange. The result of this experiment shows that the ratio of anodic reaction rate to cathodic reaction rate is not 1 , therefore the total electrochemical reaction of $\mathrm{Cu}$ electro-deposition is concluded to be polarized. The polarization that caused by the difference in reaction rate is known as kinetic polarization.

In this research the potential of half cell anode and half cell cathode were recorded in order to study the redox reaction at equilibrium condition and observed that after 25 minutes the $\mathrm{Cu}^{2+}$ absorbance was constant, which indicated that the reaction has reached equilibrium. The half cell potentials are listed in Table 5. It shows that the half anode, half cathode and the cell potentials were increased as the concentration of $\mathrm{Cu}^{2+}$ was increased. This result is in agreement with equation (11) and (12) in which the cathode potential, $\mathrm{E}_{\text {cathode }}$ is increased as the $\left[\mathrm{Cu}^{2+}\right]$ increase, meanwhile the anode potential, $\mathrm{E}_{\text {anode }}$ is reversed to $\left[\mathrm{H}^{+}\right]$ or it is increased when the $\mathrm{pH}$ of electrolyte solution is increased. The $\left[\mathrm{H}^{+}\right]$increased as the $\left[\mathrm{Cu}^{2+}\right]$ was increased. However, during electro-deposition, the $\mathrm{pH}$ of solution was decreasead which indicated the production of $\mathrm{H}^{+}$.

$$
\begin{aligned}
& E=E^{o}+\frac{R T}{2 F} \ln a_{C^{2+}} \\
& E=E^{o}-\frac{R T}{n F} \ln \frac{a_{H^{+}}^{2} . a_{O_{2}}^{1 / 2}}{a_{\mathrm{H}_{2} \mathrm{O}}}
\end{aligned}
$$

Table 3. The $\mathrm{pH}$ of solution and the concentration of $\mathrm{H}_{2} \mathrm{O}$ during anodic reaction before it reached equilibrium.

\begin{tabular}{cccccc}
\hline $\begin{array}{c}\mathrm{T} \\
\text { (minutes) }\end{array}$ & $\mathrm{pH}$ & {$\left[\mathrm{H}^{+}\right] \mathrm{M}$} & {$\left[\mathrm{H}^{+}\right]_{\mathrm{n}}-\left[\mathrm{H}^{+}\right]_{\mathrm{o}}=2 \alpha$} & $\alpha$ & {$\left[\mathrm{H}_{2} \mathrm{O}\right] \mathrm{M}=\left[\mathrm{H}_{2} \mathrm{O}\right]_{\mathrm{o}}-\alpha$} \\
\hline 5 & 4.39 & $4.07 \times 10^{-5}$ & $0.76 \times 10^{-5}$ & $0.38 \times 10^{-5}$ & $5.73 \times 10^{-5}$ \\
10 & 4.21 & $6.17 \times 10^{-5}$ & $2.86 \times 10^{-5}$ & $1.43 \times 10^{-5}$ & $5.73 \times 10^{-5}$ \\
15 & 4.04 & $9.12 \times 10^{-5}$ & $5.81 \times 10^{-5}$ & $2.91 \times 10^{-5}$ & $5.73 \times 10^{-5}$ \\
20 & 3.86 & $1.38 \times 10^{-5}$ & $10.49 \times 10^{-5}$ & $5.25 \times 10^{-5}$ & $5.73 \times 10^{-5}$ \\
25 & 3.71 & $1.95 \times 10^{-5}$ & $16.18 \times 10^{-5}$ & $8.09 \times 10^{-5}$ & $5.73 \times 10^{-5}$ \\
\hline
\end{tabular}


Table 5. Half cell potential of anode and cathode

\begin{tabular}{ccc}
\hline$\left[\mathrm{Cu}^{2+}\right] \mathrm{M}$ & $\begin{array}{c}\mathrm{E}_{\text {cathode }} \\
\text { (Volt) }\end{array}$ & $\begin{array}{c}\mathrm{E}_{\text {anode }} \\
\text { (Volt) }\end{array}$ \\
\hline 0.1 & 0.532 & 1.415 \\
0.2 & 0.543 & 1.429 \\
0.3 & 0.558 & 1.442 \\
0.4 & 0.569 & 1.452 \\
0.5 & 0.575 & 1.464 \\
\hline
\end{tabular}

The equilibrium constant was determined based on Nernst equation (equation (13)). The half cell potentials that are listed in Table 5 were used to calculate the anodic E' value and cathodic E' value by using equation (13) and (14). The standar half cell potential, $\mathrm{E}_{\text {anode }}$ was determined from linear plotting of E' versus $\mathrm{H}^{+}$concentration which was calculated from $\mathrm{pH}$ of solution. Meanwhile, $\mathrm{E}_{\text {cathode }}$ was determined from linear plotting of E' versus $\mathrm{CuSO}_{4}$ concentration (equation (14) and equation (15)). The standar cell potential, $\mathrm{E}_{\text {cell, }}^{\mathrm{o}}$ was calculated by using equation (16).

$$
\begin{aligned}
& E_{\text {cell }}=E_{\text {cell }}^{o}-\frac{R T}{n F} \ln K \\
& E^{\prime}=E+\frac{2.5 R T}{2 F} \ln \left[H^{+}\right] \\
& =E^{o}-\frac{R T}{n F} \ln 0.5-\frac{R T}{n F} \ln \gamma_{H+}^{2.5} \\
& E^{\prime}=E-\frac{R T}{2 F} \ln \left[\mathrm{Cu}^{2+}\right] \\
& \quad=E^{o}+\frac{R T}{n F} \ln \mathrm{Cu}^{2+}
\end{aligned}
$$

Tabel 6. The equilibrium constants, $\mathrm{K}$ of redox reaction in the electrochemical cell at various concentration of $\mathrm{CuSO}_{4}$ solutions.

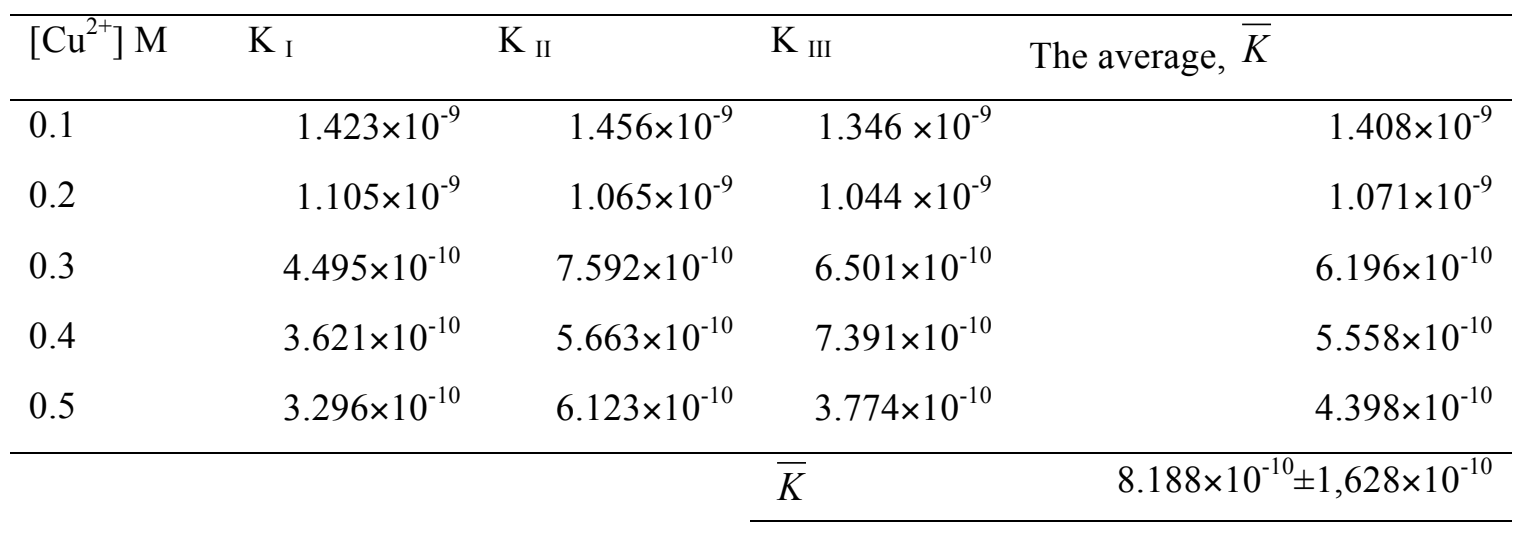

$E_{\text {cell }}^{o}=E_{\mathrm{Cu}^{2+} / \mathrm{Cu}}^{o}+E_{\mathrm{H} 2 \mathrm{O} / \mathrm{H}^{+}}^{o}$

As the $\mathrm{E}^{\prime}$ and $\mathrm{E}^{\mathrm{o}}$ were able to be determined, therefore the activity coefficient, $\gamma$, can be calculated by equation (14) for $\mathrm{H}^{+}$and by equation (14) for $\mathrm{Cu}^{2+}$. Then the activity of each ions can be calculated by equation (17) and the equilibrium constant, $\mathrm{K}$, was determined by equation (18).

$a_{i}=\gamma_{i} \cdot m_{i}$

$K=\frac{a_{O_{2}}^{1 / 2} \cdot a_{H^{+}}^{2} \cdot a_{C u}}{a_{C u^{2+}} \cdot a_{H_{2} O}}$

$\gamma_{\mathrm{i}}$ is the activity coefficient of species i and $m_{\mathrm{i}}$ is molality of species $i$ and $a$ is the activity of each species in the solution. The equilibrium constants are listed in Table 6.

\section{CONCLUSION}

The electrochemical reaction of $\mathrm{Cu}$ deposition reach equilibrium after 25 minutes. The reaction order of cathodic reaction is 1 and zero order for $\mathrm{H}_{2} \mathrm{O}$ in anodic reaction. The ratio of anodic rate reaction to cathodic rate reaction, $(\overline{\overline{r a} / r c})$ and the ratio of its reaction rate constant, $(\overline{\overline{k a} / \overline{k c}})$ show that the cathodic reaction proceed faster than anodic reaction or the electrochemical cell was under kinetic polarization. 


\section{ACKNOWLEDGEMENT}

Authors aknowledge to Farida Eriza for a good colaboration during experiment and also to Sub Lab Kimia Lab Pusat MIPA UNS to facilitate this experiment.

\section{DAFTAR PUSTAKA/ REEFRENCES}

1. Yang, H., Coombs, N., Sokolov, L., and Ozin, G. A., 1997, Registered Growth of Mesoporous Silica Films on Graphite, $J$. Mater. Chem, 7(7), 1285-1290.

2. Rahmawati, F., Kusumaningsih, T., Hapsari, A.M., Hastuti, A., 2010, Ag and $\mathrm{Cu}$ loaded on $\mathrm{TiO}_{2} /$ graphite as a catalyst for Escherichia colicontaminated water disinfection, Chemical Papers, 64 (5) 557-565.

3. Debnath, S., Ray, N.R., Ghosh, U.C., 2011, Characterization of agglomerated nanosized titanium (IV) oxide prepared by two pathways and their performance toward $\mathrm{Cu}$ (II) adsorption, International Journal of Green Nanotechnology 3, 271-280.

4. Brown, G.N., Birks, J.W., and Koval, 1992, Development and characterization of a titanium-dioxide based semiconductor photoelectrochemical detector, Analytical Chemistry, 64, 427434.

5. Hoffman, M. R., Martin, S. T., Choi, W., and Bahnemann, D. W., 1995, "Environmental Applications of
Semiconductor Photocatalysis", Chem. Rev. 95, 69-96.

6. Zhu, J., Lu, M., Li, M., Zhu, J., Shan, Y., 2012, Synthesis of carbon-titania composite and its application as catalyst support, Material Chemistry and Physics 132, 316-323.

7. Gunlazuardi, J., 2001, Fotokatalisis pada Permukaan $\mathrm{TiO}_{2}$ : Aspek Fundamental dan Aplikasinya, Seminar Nasional Kimia Fisika II, Universitas Indonesia, Jakarta.

8. Rahmawati, F., Wahyuningsih, S., Handayani, N., 2008, Surface modification of semiconductor thin film of $\mathrm{TiO}_{2}$ on graphite substrate by $\mathrm{Cu}$-electro-deposition, Indonesian Journal of Chemistry, 8 (3) 331-336.

9. Li, P., Li, T.,Zhou, J.H., Sui, Z.J., Dai, Y.C., Yuan, W.K., Chen, D., 2006, Synthesis of carbon nanofiber/graphitefelt composite as a catalyst, Microporous Mesoporous Materials 95, 1-7.

10. Hanzu, I., Djenizian, T., Ortiz, G.F., Knauth, P., 2009, Mechanistic study of Sn electrodeposition on $\mathrm{TiO}_{2}$ nanotube layers: thermodynamics, kinetics, nucleation, and growth modes, Journal of Physical Chemistry 113, 2056820575.

11. Prentice, G., 1991, in: Electrochemical Engineering Principles, Prentice Hall. Inc., New Jersey, 93-150. 